\title{
市民参画による腰越漁港改修計画の検討 PLANNING METHOD OF FISHING PORT IMPROVEMENT WORKS BASED ON PUBLIC INVOLVEMENT
}

\author{
清野聡子 1 - 宇多高明 $2 \cdot$ 山崎一真 $3 \cdot$ 安部和典 $4 \cdot$ 大谷 保 $5 \cdot$ 大塚浩二 6 \\ Satoquo SEINO, Takaaki UDA, Kazuma YAMAZAKI, Kazunori ABE, \\ Tamotsu OTANI and Koji OTSUKA
}

\author{
1正会員 農修 東京大学大学院総合文化研究科広域システム科学科助手 (テ153-8902 東京都目黒区駒場 \\ $3-8-1)$ \\ 2正会員 工博 国土交通省土木研究所河川部長 (テ305-0804 茨城県つくば市旭1) \\ 3鎌倉腰越まちづくり市民懇話会会長(前腰越のまちづくりを考える鎌倉市腰越漁港改修検討委員座長) \\ （テ248-0033 神奈川県鎌倉市腰越791-4） \\ 4鎌倉市市民活動部農水課長（厂248-8686 神奈川県鎌倉市御成町18-10） \\ 鎌倉市市民活動部農水課長補佐（厂248-8686 神奈川県鎌倉市御成町18-10） \\ 6 正会員 (財) 漁港漁村建設技術研究所 (T101-0047 東京都千代田区内神田1-14-10 東京建物内神田ビル)
}

In the planning of the improvement works of the fishing port to enhance its utilization level, it is usual to reclaim the surrounding area of the port. However, in case where the rich fishing ground is located in the vicinity of the port, the enhancement of utilization as well as upgrading of the port function and conservation of the marine environment become in conflict. Harmony of these conflicting conditions is becoming a serious problem in the development of the fishing port and its ambient area. This study aims at the creation of work scheme to reach consensus between local people for the improvement plan in harmony with environmental conservation in the surrounding sea area, taking Koshigoe fishing port in Kamakura City, Kanagawa Prefecture as the example.

Key Words : Fishing port, public involvement, ecosystem

\section{1. まえがき}

近年，各種公共事業の推進形態に対して市民が異 議を唱えることが多くなり，そうした状況に対応し て事業のあり方を改善するために国・地方を問わず 情報公開に基づいた合意形成が重要な課題となって いる.しかし合意形成の重要性は螵われてはいるも のの, 実際の合意形成の場を通じてそのあり方を探 るという研究は少ない.筆者らはこの種の問題につ いては実践的な取り組みに基づく事例研究の蓄積が 必要と考え, このため種々の合意形成問題に係わっ てきた.その一例として, 住民合意に基づいて海岸 事業を進めるための懇話会方式を提案し, 住民の考 え方を十分理解するとともに, 住民からの提案をも 取り入れることのできる仕組み作りを青森県大畑町 木野部海岸で進めてきた ${ }^{1)}$ 2)．このような取り組み は今後海岸事業のみではなく, 海にまつわる各種事 業, すなわち港湾や漁港事業においても必要となる
と考えているが, 今回, 神奈川県鎌倉市の腰越漁港 の改修および周辺環境に及ぼす影響に関連して, 市 民との合意形成問題が発生した.このため, 公募に よる市民委員も交えた委員会による協議方式が市民 から提案され, 市長の私的謋問委員会が設置された. 筆者らはそれに委員扩よび事務局しして参加し, 多 くの人々との徹底した議論のもとに, 最終的な合意 を得つつある.この小論では, 同様な問題を抱える 場所における今後の問題解決の一助となることを期 待して, その経緯についてまとめる.

\section{2. 腰越漁港の現状}

腰越漁港は，図-1に示すように神奈川県鎌倉市の 小動岬の西側に隣接する第1種漁港であり, 相模湾 を漁場とする小型定置網, 船びき網, はえ縄, ワカ 入養殖等の沿岸漁業・海面養殖業の基地となってい 


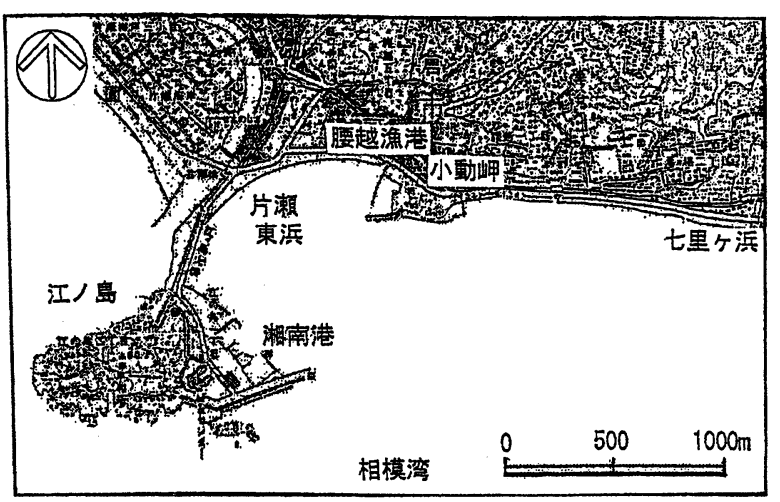

図-1 鎌倉市腰越漁港の位置

$3^{3)}$. 近年, 腰越漁港では遊漁案内業との複合経営 が一般化しているほか, シラス加工や漁獲物・加工 品の直売が行われるなど, 漁港利用も多様化してい る. 腰越漁港では, 現在, 係船岸が不足するととも に港口付近にある岩礁により漁船が横波を受ける危 険, さらには泊地の静穏度が低いことから荒天時に は油壶湾へ避難しなければならないことなど, 多く の問題を抱えている（図-2）。こうした場合，一般 には直ちに漁港施設の改修が行われるのが常である が, この漁港の場合, 漁港南岸沖の露岩域 (藻場)が 良好な漁場でもあるため, その漁場で埋め立てなど の地形改変を行えば良好な漁場を自ら埋め立ててし まうという問題点を抱えている3)。

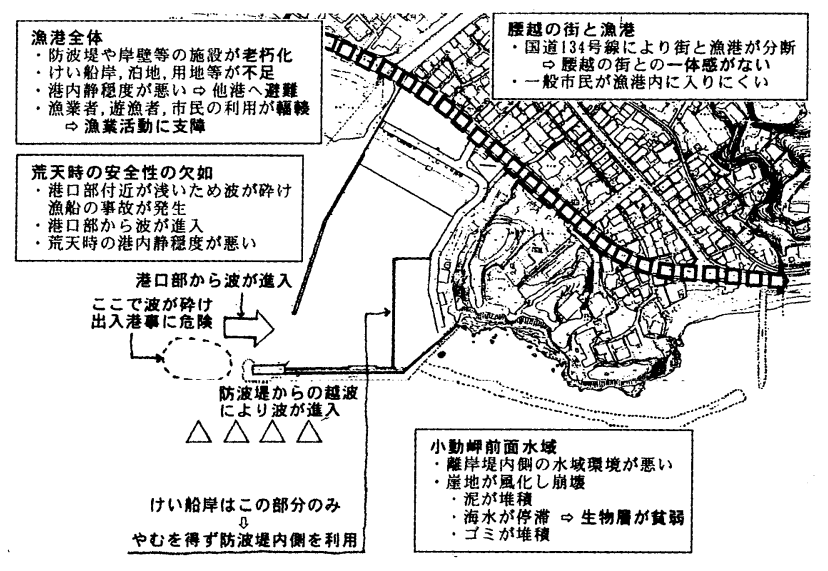

図-2 腰越漁港が抱える問題点

\section{3. 市民参画による腰越漁港改修検討委員会の 経緯}

鎌倉市では，市の総合計画において「沿岸漁業の 振興」を基本構想に位置付け, 具体的事業として 「漁港施設整備事業（腰越漁港改修および周辺環境 整備事業）」を掲げた.この事業の推進にあたって は市民参画を基本とするとともに，これを具体化す るための手法について1997年, 市民からアイデア募 集を行った.その結果，「市民や専門家からなる組 織で検討し，その検討案を市民に提示して欲しい」
との提案があった.

実際には, 当初から市民参画を取り入れた計画作 りが考えられていた訳ではなかった. 漁港施設整備 事業の計画は漁業者からの意見を聞く中で, 行政主 導により進められており，1993年にはその基本計画 案ができていた. その第1段階は腰越漁港のある小動 岬東側での海岸整備と海食崖の崩落防止事業であっ た. 1996年には県からの補助金も内示され，近隣の 自治町内会への広報も終えて着工を待つばかりで あったが, 直前になってサーファーを中心とする団 体等から事業の効果と必要性等についての問題提起 があった. 具体的には, 本当に侵食や崖の崩落が進 んでいるのか, 事業実施の効果があるのか, そして 環境破壊はないのかを中心に, 絶好のサーフポイン トが失われることなどを危惧したものであった.こ の運動は, 市議会はもちろん, 国, 県, マスメディ アも巻き込んだものとなったが, 最終的には1997年 2 月, 腰越中学校体育館で約 200 人の市民が参加して 大激論が行われるとともに専門家の意見を聞く中で, 市はこの事業の緊急性はないと判断し, 結果として 第1段階に予定した事業は中止となり, 同時に漁港 改修計画も最初から検討せざるを得なくなった. 前 述のアイデア募集はこうした経過の中から出てきた.

このことから，1998年7月1日発行の「広報かまく ら」により市民委員を公募し, その結果選出された 委員6名のほか, 専門家2名, 漁業者2名（1999年10 月からは3名）, 行政2名（神奈川県職員）からなる

「腰越のまちづくりを考える腰越漁港改修検討委員 会」が発足し，1998年11月5日に第1回の検討委員会 が開催された ${ }^{4)}$.

委員会での検討事項は, (1)漁業振興のための漁港 の規模, (2)非常時の海上輸送拠点としての整備, (3) 腰越のまちづくりに役立つ機能の付加, (4)環境や景 観, 周辺域への影響に関する事項などであった.こ のように政策策定段階から市民参画を基本として合 意形成を図る試みは全国の漁港事業におけるさきが け的事例であった。

本来, 漁港改修は多額の経費を必要とするため, 国・県の補助を必要とし，そのための協議や許認可 等が必要となるが, 基本的な計画作りは市町村に よって行われる.この場合にも多くは漁業者を中心 とする関係者と, 行政の協議で決定されるものであ り, 改修によって明確な不利益を受ける者がいる場 合には, そこで協議が行われ，調整されて計画が作 られる.今回の腰越漁港改修計画にあっては, 不利 益を受ける者は明確でなく, その問題点が漁業のあ り方, 生態系・景観などの環境問題, さらには公共 事業のあり方など, 一般的なものであったことが重 要な意味を持つところである.

検討委員会は, 市民参画を基本として会議開催の 広報, 傍聴制度による公開, 会議資料や議事録の公 開等, あらゆる情報の公開方針のもと, 全体で15回

（意見交換会含む）の検討を重ねた.この間，遊漁 船問題や環境問題等の調查・研究はもとより, 漁 港・漁場の現地視察や漁業者の意向調査を行った. 
また，市民の合意形成に基づく改修計画の立案をめ ざす立場から，市民との意見交換会を2回実施した. この検討会では, 海域環境の劣化を最小限にしつつ 漁港規模の拡張について検討するという困難なテー マが主題となるとともに, 強い公共事業批判の中で 何故そのような事業が必要かについて多くの人々に 理解を得ることが必要とされた。

\section{4. 遊漁船問題}

市民との意見交換会も含め, 検討委員会で特に議 論が集中したのは漁業と遊漁船の関連であって，遊 漁船業は一次産業としての漁業ではないのでそれに 公費を使うことは問題ではないかという指摘であっ た.そこで「遊漁船業の適正化に関する法律（昭和 63 年法律 99 号）」や「海面遊漁のあり方について （水産庁通達）」など，遊漁船業に関する法制度に ついて検討した. また漁業者との意見交換やアン ケート調査を行った結果，遊漁船業者のほとんどは 沿岸漁業との兼業であって, 多くの漁業者にとって 現状は漁業専業だけで生計の維持は困難であり, 遊 漁船業は漁業者の所得向上と漁村の活性化に大きな 役割を果たしていること，さらに多くの漁業者は将 来的には本来の漁業をめざしたいとする意向である ことが確認された。

このほか遊漁船については環境や生態系の面から の議論も行われた.国の通達に基づいて設置された 相模湾東部地域遊漁協議会での申し合わせ事項はあ るものの，遊漁船利用者が大量に使うコマセが海底 に堆積し環境污染を起こすこと，遊漁船利用者が排 出するゴミの問題, 乱獲による魚種への影響等も提 起された. 腰越漁港独自のルール化, 例えばゴミの 持ち帰りや入漁料の特別徴収, 大漁の場合は, 一部 を漁協が買い上げて市民へ安価で供給することなど の必要性も明らかにされた.

\section{5．漁業者との意見交換}

1999年4月15日, 漁業者が奏際にどのような漁業 活動を行っているのか, 現在の漁港ができるまでの 変遷やできてからの課題等について漁業者との意見 交換を行った. 現地視察では腰越漁港が開催してい る魚の直売（朝市: 毎月第1, 3木曜日）の状況を視 察した後, 実際に漁船に乗って腰越の漁場やワカメ の養殖棚，シラス船引漁等を漁業者の説明を聞きな がら視察した. また腰越漁業協同組合員を対象にし たアンケート調查を実施した結果, 以下の意見が出 された.

(1) 多くの漁業者が将来も漁業を行っていきたい と望んでいること

(2) 蓄盖, 加工, 直売等を通じて, 獲るだけの漁 業だけではなく，つくり育てる漁業への転換を
図っていくことにより高齢漁業者も就業機会が 増えると考えていること

(3) 大型定置網の廃業による減少を除けば，漁獲 量，水揚げ金額とも概ね一定の量・金額を維持 していること

(4) 後継者については新規参入者が増加傾向にあ るが，高齢割合も高いために，総数としては約 80名前後で推移していること

\section{6. 漁港改修の基本方針と改修計画案（ゾー二 ング)}

検討委員会では，漁港改修のための基本方針とし て，(1)安全で夢のある漁港の創造（安全と海洋環境 を積極的に追求していく漁港），(2)海洋資源に関す る循環型地域社会づくり（漁業者, 商工業者と市民 の共存共栄），(3)水域環境の回復イニシアチブ（周 辺環境改善漁港の創造）を定めた.これらの方針の もとで改修範囲を決定するために，腰越漁港に係る 各種制約条件（図-3参照）や市民利用の観点などを 考慮してゾーニング検討を行った（図-4）.

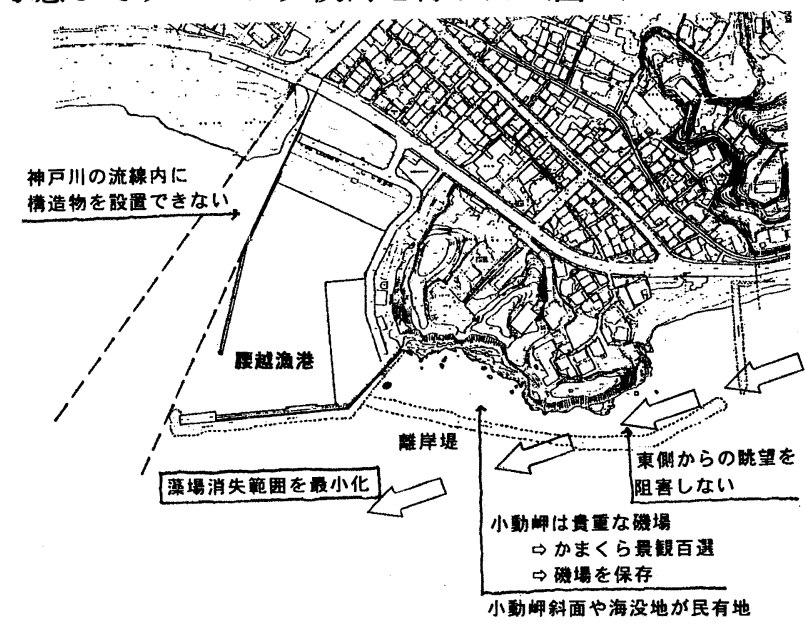

図-3 腰越漁港改修の制約条件

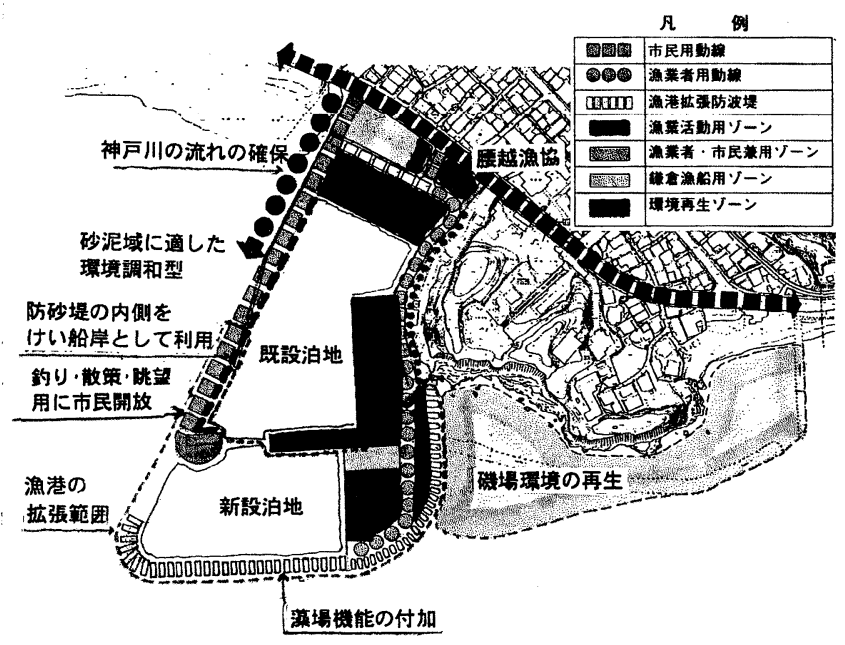

図-4＼cjkstart腰越漁港の改修範囲のゾーニング 


\section{（1）神戸川防砂堤}

腰越漁港西側の片瀬東浜は閉鎖性海浜であり, 腰 越漁港の南側の露岩域にある藻場と比較して生物環 境上相対的に重要度がやや低いと考えられること から, 当初, 漁港を西側に広げる案について検討し た.しかしながら神戸川は河口に架かる腰越橋でそ の法線が現導流堤と平行となっているため, 橋梁の 付け替を行わずに神戸川の法線を変えることは困難 との結論に達し, 既存防砂堤を直線状に延長する以 外方法がないことがわかった.一方，市民が䄭い気 軽に利用できる漁港とするためには, 広さとそこへ の動線が必要である.そこで防砂堤を拡幅し, その 一部と先端を市民の眺望・休蒩の場 (市民ゾーン) と して整備する案を考えた。

\section{（2）小動岬側新防波堤}

当初小動岬前面の離岸堤と海食崖に囲まれた水域 を埋め立てて漁港施設用地とする案が検討された. この水域は漁業には使用されていないが，用地とし て利用するとすれば崖地の保全対策が必要となる. そこで小動岬周辺の土地所有権を調查するとともに, 崖地保全に必要な工法やその経費について検討した 結果, 小動岬が海食崖として侵食されてきた経緯か ら官民境界が明確でなく, 海没民地に関する法律的 問題が残ること, さらには1999年，小動岬が「かま くら百選」に選定されたことから埋め立ては行わず, 水域としてそのまま存置することとした.さらに鎌 倉の海岸で磯として残された場所は小動岬前面の水 域, 稲村ケ崎, 和賀江島のみであることから, 当該 水域は鎌倉市で非常に貴重なものと位置付けられた. また, 離岸堤により外海と隔離されているとはいえ 浅い水域は多様な生物の生育場として重要であり, 将来的には磯の観察が可能な場所としてのポテン シャルも有することから, そのまま存置することが 必要との結論に達した. 以上の検討を受けて, 小動 岬側の新防波堤は, 小動岬に接する既存防波堤の基 部を原点として, そこから南向きに延ばした線を東 側の境界線とした.

\section{（3）港口部の位置}

港口は, 港内堆砂の浚渫を減らすために, 前報3) で明らかにした漂砂移動の少ない水深 $3 \mathrm{~m}$ 以上の場所 に設けることにした.また現港口の前面には岩礁が あり，これによって航行時に危険な波が発生してい ることからこれを回避する形状とした.

\section{（4）新防波堤}

漁港整備による海岸環境の変化については, 小動 岬に隣接する片瀬東浜, 七里ヶ浜への影響を極力小 さくするよう, 施設の位置・形状について検討した. 従来の方法では, 実施設計段階で各種シミュレー ションを行い，それをもとに決定がなされるが，今 回は基本構想段階から専門家の意見をもとに改修に よる周辺海浜や潮流への影響が小さくなるよう配慮 した. 周辺海浜へ及ぼす影響の最小化においては,
新設の防波堤が小動岬の陰に入り, 七里ケ浜側に波 の反射や遮蔽域が形成されないような案を専門家の 経験に基づいて提案した.この案では同時に, 小動 岬の沖合で往復モードを有する潮流に対する影響を 極小化できると考えた.

新防波堤は，基本的に既存防波堤とほぼ平行とし， 曲線を用いることにより反射波の影響低減を図った。 既存防波堤からの沖側への突出量は, 周辺水域や海 岸への影響, 七里ヶ浜からの眺望, 藻場等生態系へ の影響，漁船の操船や鎌倉漁協用の船揚場の設置等, 施設用地との兼ね合いなどから総合的に判断して決 定した. 検討委員会ではゾーニングを考える中で, 漁業者との話し合いを経て, 当初沖出し幅を $100 \mathrm{~m}$ （図-5参照）とする案を検討した.この案は漁業者 との話し合いで出された安全操業や必要な蓄養場所 などに配慮したものであって, 水産庁基準から見て も通常漁港内の泊地に必要な幅（最大船舶の長さ $20 \mathrm{~m} \times(4 \sim 6$ 倍)） に収まるものであった. しかし沖出 し100m案は眺望や生態系への影響などいくつかの問 題点が指摘された.

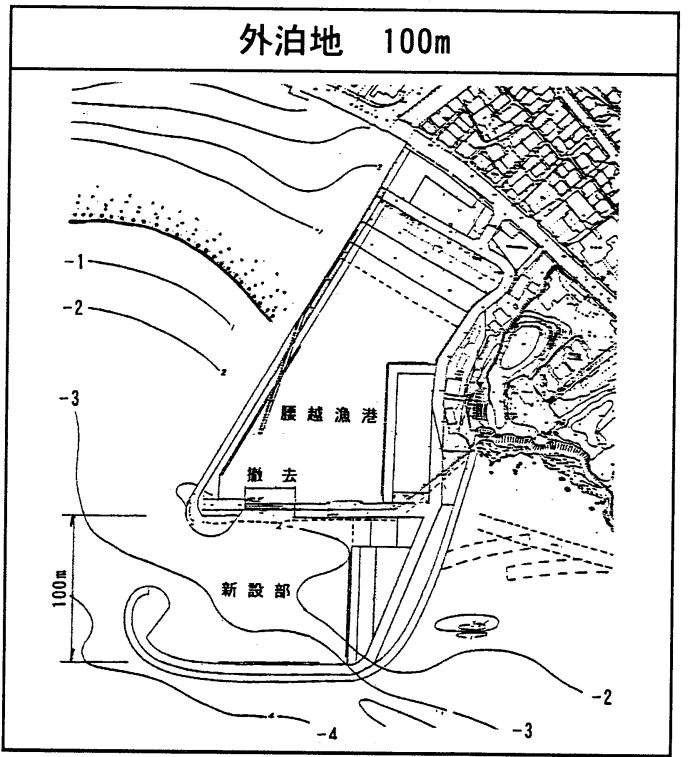

図-5 腰越漁港の当初改修案

そこでこれらの問題点を最小限に押さえ，かつ漁 業者の意向も最大限尊重した案として, 図-6に示す ように沖出し長さを $100 \mathrm{~m}$ とし防波堤の形状を曲線に する案, 沖出しを $90 \mathrm{~m}$ と既存の防波堤を内側に移 動することにより泊地を $100 \mathrm{~m}$ とする案, 沖出しを $80 \mathrm{~m}$ とする 3 案を提示し, 検討の結果最終案として 80m案を採択した.

漁港の改修が景観に及ぼす影響については, 七里 ヶ浜から稲村ヶ崎にかけての海岸線からの眺望の変 化を中心に検討した. 海岸線に境界を与える岬や突 堤等が大きく迫って見える場合と，遠方にかすんで 見える場合では海岸の開放性が異なる.これを判断 する一つの指標が境界視距離であり, 海岸線を分断 する印象を与えない距離が約 $1.2 \mathrm{~km}$ であるとされて いる ${ }^{5)}$ が, 小動岬から東側に近接する区域では漁港 施設は小動岬の陰に入り見えず，一方，それより 


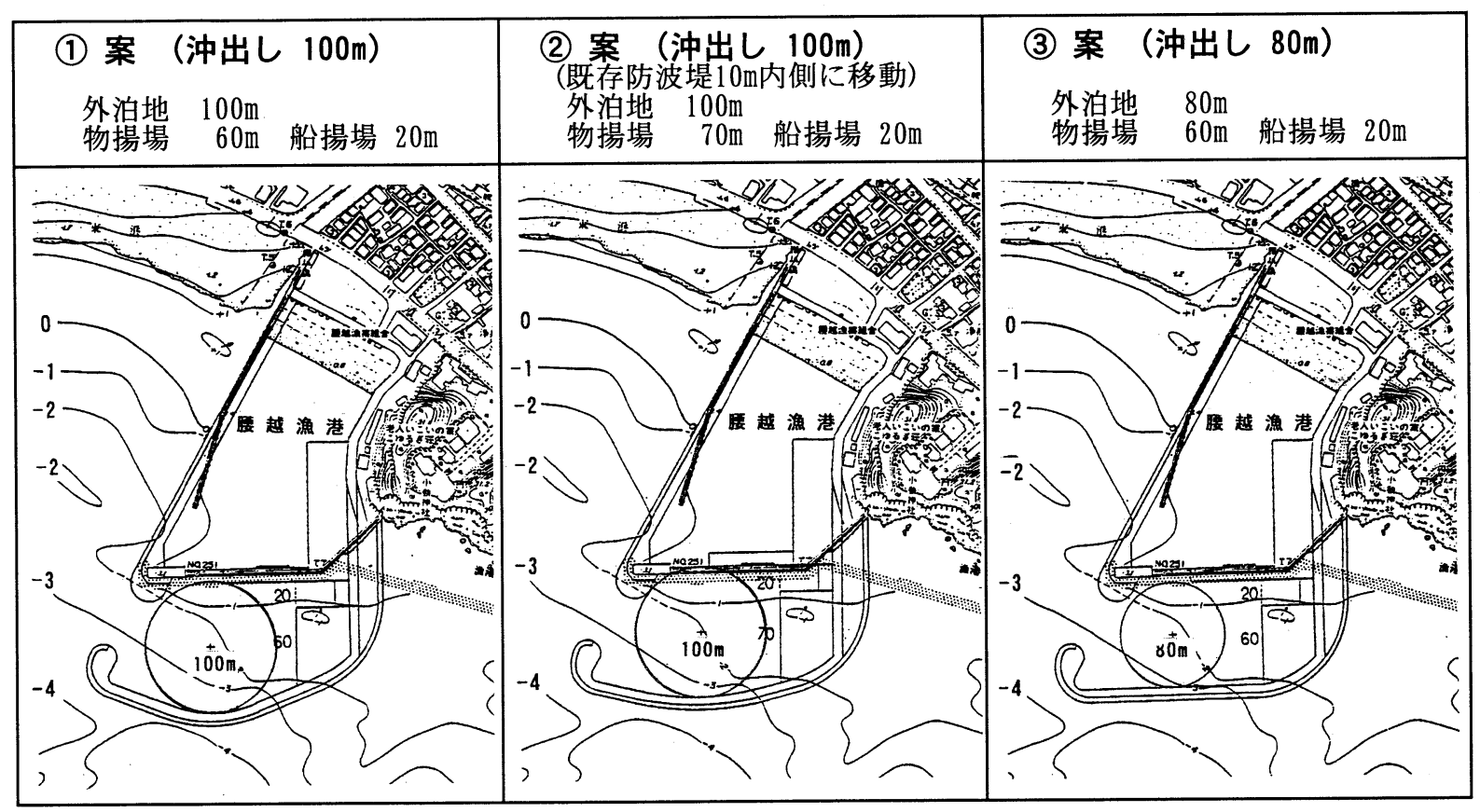

図-6 腰越漁港の改修案

離れた高台の住宅地からの俯瞰では漁港施設が遠望 されるものの, 広い視野と高さがある分景観への影 響が小さくなることが判明した.さらに有名な観光 地であり，小動岬の東 $2.6 \mathrm{~km}$ に位置する稲村ヶ崎か らは肉眼での視認ができないほど防波堤が小さくな ることから，景観に及ぼす影響はほとんどないと判 断された.

\section{7. 市民との意見交換会とそれに基づく提言}

市民との意見交換会は，検討委員会としての検討 が概ね済み，たたき台が示せる段階となった 2000 年 3月に「広報かまくら」により市民への参加を呼び かけた後，3月26日と5月21日に開催し，それぞれ約 200名の市民が集まり，高い関心が示された.1回目 の意見交換会では，より多くの意見を聞くためにア ンケート調査とダイレクトメールによる参加者から の意見募集を行った.その結果67名から177項目に及 ぶ意見が奇せられた.第1回の意見交換会で出された 課題と意見を分類し，郵送による直接回答を行うと ともに第2回の意見交換会においてもその回答と説 明を行った。

主な課題は次の5点に分類された. 1)行政自体に対 する意見，(2)遊漁船問題，(3)漁港改修の費用対効果, (4)漁港改修の必要性，(5)景観および環境の保全であ る.課題の多くはすでに検討委員会で議論されたも のであるが, 新たな観点として, 今回の漁港改修が どのような考えや計画のもとで出てきたのか, また 上位計画があるならばそれらの情報は公開され，市 民に示されているかという問題であった. またミテ イゲーションの可能性と実現性, 睘境調査の結果と 公表, 漁港の維持管理にかかる経費の現状と将来予 測等について意見が交わされた.もちろん漁業者の
窮状を擁護する立場から，あるいは漁港が腰越地区 のまちづくりの拠点であるとの認識から, 早期の事 業推進を要望する声も出された.

これらの意見や疑問に対しては検討委員会や市か らこれまで検討してきたことや考え方を報告し，議 論を尽くした結果，一部の市民に反対や慎重論はあ るものの概ね市民の理解が得られたものと考えた. なお意見交換会に参加した市民の基本的な考え方は, すでに640兆円を超える国, 地方公共団体の負債が ある状況下で公共事業がいかにあるべきかという問 題であった.こうした状況のまま公共事業が行われ れば, 自分達や子孫への負担が今後益々増えること が懸念され，また市民からその無駄を指摘され中止 になっている事業もある中で, この漁港改修をどう 考えていくべきかということであった. 委員会とし てもこの考え方に全面的に賛成するとともに，こう した指摘を受けないよう政策の策定段階から市民参 加を基調として進めてきたことを説明し，広く理解 を得た。

一連の封議の結果, 検討委員会としては次の提言 を行った.

(1)腰越漁港改修計画は, その結果として遊漁案内 を含め漁業関係者が恩恵を受ける部分が大きい.だ からこそこの改修は今後の漁業の持続的な発展を視 野に入れた改修でなければならず, 漁港改修は漁業 者のためだけであってはならない. 市民全体が利益 を享受すべきである.市民はこの漁港改修から何を 還元してもらえるか, という声は検討の過程で多く の委員や市民が述べている. とくに漁獲物の地元へ の還元が目に見える形で行われることへの期待は大 変大きい.このことを十分認識し, 流通や魚商関係 者, 消費者との協議を含めて市としても積極的に対 応していくべきである.

(2)現在，そして次世代に向けて考えなければなら 
ないことは環境保全である.今後のモニタリングや ミティゲーションの中で, 改修内容を決定するにあ たり，市民がその検討に参加できるようにしておく ことや，全ての情報を公開していくことが必要であ る.

(3)遊漁船が抱える環境污染への対策や漁港の運用 等については，腰越独自のルール化を図ることが必 要である.

\section{8. 考察}

\section{（1）過去の行政に対する不信感の除去}

前述のように, 腰越漁港の整備については, その 関連事業が過去に検討され，市民の合意に至らな かった経過がある.市民との意見交換会に出席した 市民はそのことを明瞭に記憶しており，市の過去の 行政に対して基本的な不信感を有していた. このた め, 今回の合意形成においては, 過去の話と今回と の計画について合意形成のプロセスを含めて違いを 明らかにすることが必要であった. 各地の各種公共 事業で合意がなされていないものについては必ずこ の種の問題があり，そのような問題の処理が必要と される.ここでは，過去の計画の不十分な点を検討 委員会側から十分に説明し，新しい計画ではそれら を改善した案を提出することによって最初にあった 不信感が徐々に少なくなっていった.

\section{(2)最終合意のプロセス}

市民との意見交換会では，漁港の建設を望む漁業 者が多く参加し，漁業組合員の生の声を聞くことが でき, 特に若い漁業者を待つ妻の心境や，老年の漁 業者が, 海難事故(例えばサーファーの流出事故)な ぞにおいて自己の生命をかけてまで救助に向かう状 況などが直接話された.これらの意見のうち，特に 人の生命に係わろ話は，海の環境保護を主張する 人々にも深い感銘を与えたことが議論の場が急に静 まったことからうかがわれた. 当然, 環境保護を主 張する人々からの発言も多くあったが，意見交換会 の最終段階では意見が出尽くした状況となり，しか たがないという意味でほぼ合意に達した.これも建 設を望む漁師達と, 環境を守ることを主張する環境 派の間での徹底した議論があったためと考えられる. その意味で公開のもとでの徹底した討論の必要性が 改めて確認された.

\section{（3）市民参加を可能にする地域性}

漁港事業では市民参加のプロセスを制度的に位置 付けていないが, 本委員会のような形式で市長の私 的諮問機関として市民参加の委員会が組織されたこ とは，漁港管理者である市行政の決断である.これ は鎌倉市の地域性による部分が大きいと考えられる.
すなわち

(1)公共事業に対して市民参加や徹底した議論を市 民が要望する精神風土が形成されている. 地域計画, 福祉やリサイクルなどでの市民参加は先進的な地域 であるため，市の他事業でも行われている方法で あった. そのため, 市行政のなかでのコンセンサス も形成されやすい土壌がある.

(2)社会制度の変革を地域から行うことを厭わない 地域である. 社会実験（例．パーク・アンド・ライ ド）を受容し参加し，体験するなかから具体的提案 をするなど，市民が新しい社会的枠組をつくること に熱心である ${ }^{6)}$.

(3)少数意見であっても押さえ込まず，報告書に記 載し検討を続けるなど，価值観や意見の多様性を認 める風土があり，この委員会の報告書においても行 われた.これは市民がこういった会議の詳細につい て真剣に考え参加する習慣があってこそ生まれる緊 張感であって，全国どこでも同様な状況にある訳で はない.

これらの地域社会的背景があって漁港計画への市 民参加と合意形成が進められたと考えられる. 今後 の事業の実施に，また施設や周辺環境の長期的な管 理に対してもこれらの議論が反映されることが望ま れる。

謝辞 : 10 回を超える検討委員会において貴重なご意 見をいただいた委員の方々，2回の意見交換会に参 加していただき活発な議論を展開していただいた市 民の方々，および市民参画による合意形成を目指し 事務局として支援していただいた鎌倉市企画部拠点 整備課, 緑地海浜部海浜課および建設部道路課・住 宅建築課の方々など, 多くの方々に謝意を表します.

\section{参考文献}

1) 宇多高明・清野聡子・花田一之・五味久昭 - 石川仁 憲・芹沢真澄 : 住民合意型海岸事業の推進方法-青森県 大畑町木野部海岸での新しい試孔, , 海洋開発論文集, 第16巻, pp. 523-528, 2000.

2) 清野聡子・宇多高明・花田一之・五味久昭・石川仁 憲・太田慶正 : 住民合意に基づいた海岸事業の進め方 に関する研究-青森県大畑町木野部海岸の事例-, 環境 システム研究論文集, 第28巻, pp. 183-194, 2000.

3) 安部和典 - 大谷 保 - 清野聡子 - 宇多高明 - 大塚浩 二：鎌倉市腰越漁港における漁港改修と海域環境保全 に関する一考察, 海洋開発論文集, 第 16 巻, pp. 529$534,2000$.

4) 腰越のまちづくりを考える鎌倉市腰越漁港改修検討委 員会 : 鎌倉市腰越漁港改修検討報告書, p. 13，2000.

5)宇多高明・小俣 篤・浅対 亮 : 海岸の温熱環境と快 適性の関係および海岸の空間規模の評価法に関する研 究, 土木研究所資料, 第2939号, p. 64, 1991.

6) 山崎一真編「社会実験-市民協働のまちづくり手法」, 東洋経済新報社, 1999 . 